\title{
Assessment of genetic variability, heritability and genetic advance in $\mathbf{F}_{6}$ population of desi chickpea (Cicer areitinum)
}

\author{
Muhammad Kashif Nawaz ${ }^{1}$, Amir Sohail ${ }^{1 *}$, Tanvir Burni ${ }^{2}$, Shahzad Ali ${ }^{3}$, \\ Manzoor $^{4}$, Sada Bahar ${ }^{1}$ and Quaid Hussain ${ }^{1}$ \\ 1. Department of Plant Breeding and Genetics, The University of Agriculture, Peshawar-Pakistan \\ 2. Department of Botany, University of Peshawar-Pakistan \\ 3. College of Agronomy, Northwest A \& F University, Yangling-China \\ 4. Department of Agronomy, The University of Agriculture, Peshawar-Pakistan \\ *Corresponding author's email: amirsohail@aup.edu.pk \\ Citation \\ Muhammad Kashif Nawaz, Amir Sohail, Tanvir Burni, Shahzad Ali, Manzoor, Sada Bahar and Quaid Hussain. \\ Assessment of genetic variability, heritability and genetic advance in $\mathrm{F}_{6}$ population of desi chickpea (Cicer \\ areitinum). Pure and Applied Biology. Vol. 7, Issue 1, pp194-200. http://dx.doi.org/10.19045/bspab.2018.70023 \\ \begin{tabular}{llll}
\hline \hline Received: 07/07/2017 & Revised: 18/01/2018 & Accepted: 24/01/2018 & Online First: 31/01/2018 \\
\hline
\end{tabular}
}

\section{Abstract}

The research was conducted to estimate genetic variability, heritability and genetic advance in $\mathrm{F}_{6}$ population of desi chickpea during rabi season 2015-16. The experimental material comprised of $19 \mathrm{~F}_{6}$ lines along with one check cultivar were studied in randomized complete block design with three replications. Analysis of variance showed significant differences $(P \leq 0.01)$ among the $F_{6}$ chickpea lines for all the studied traits. line $\mathrm{C}_{2}-\mathrm{P}_{7}-1-1$ showed maximum mean value for days to maturity (123.7), seed pod $^{-1}$ (1.9) and harvest index (27.7\%), whereas, line $\mathrm{C}_{2}-\mathrm{P}_{8}-2-5$ exhibited maximum mean value for plant height $(68.3 \mathrm{~cm})$, primary branches plant ${ }^{-1}(3.8)$ and biological yield $\left(2010.6 \mathrm{~kg} \mathrm{ha}^{-1}\right)$. Maximum pods plant ${ }^{-1}$ (28.8) was attained by line $\mathrm{C}_{2}-\mathrm{P}_{8}-3-1$, whereas, maximum secondary branches plant ${ }^{-1}$ (8.8) were noted for $\mathrm{C}_{2}-\mathrm{P}_{8}-3-4$. Moreover, $\mathrm{C}_{2}-\mathrm{P}_{7}-1-8$ exhibited maximum mean value for 100 seed weight $(25.9 \mathrm{~g})$ and grain yield $\left(463.8 \mathrm{~kg} \mathrm{ha}^{-1}\right)$. Genetic variances of all the traits were greater than environmental variances. Genetic advance was for days to maturity (15.46), plant height (5.98), primary branches plant ${ }^{-1}(0.60)$, secondary branches plant ${ }^{-1}(1.67)$, pods plant ${ }^{-1}(5.81)$, seeds pod ${ }^{-1}(0.24)$. 100 Seed weight (3.17), seed yield (209.58), biological yield (598.45) and harvest index (7.00). It could be concluded that high values of heritability and genetic advance for a characters like secondary branches plant ${ }^{-1}$ and pods plant ${ }^{-}$ ${ }^{1}$ suggested appropriate selection criteria and could be effective in a future breeding programs.

Keywords: Chickpea (Cicer areitinum); $\mathrm{F}_{6}$ Populations; Genetic variability; Genetic advance;

Heritability

\section{Introduction}

Chickpea (Cicer areitinum) also known as Gram, Bengal gram, belongs to family Fabaceae and subfamily Papelionaceae. It is a winter crop grows widely in arid and semiarid region of the world. It is the third valuable pulse crop throughout the world next to dry bean and field pea and first in 
south Asia for it area and production. It is a highly self-pollinated crop (99\%) [1].

Chickpea is one of the important legume worldwide due to its nutritive value. Chickpea's seed contain 18-24\% protein, $57-60 \%$ carbohydrates and less than $10.5 \%$ fats [2]. Chickpea is the only cultivated species among the 43 species of the Cicer genus. There are about 40,000 accessions of chickpea in the world. Cultivated chickpeas are divided into 2 main groups, Desi and Kabuli groups. Desi chickpea seeds are small, darker colored and wrinkled. Kabuli seeds are larger cream-colored and contain less fiber as compared to desi chickpea [3].

Worldwide during 2014 the total area under chickpea cultivation was 14.80 million hectares, with a production 14.23 million tones and with an average yield of 0.96 tons per hectare [4]. In Pakistan during 2014 the total area under chickpea cultivation was 0.94 million hectares, with a production of 0.39 million tons and with average yield 0.42 tons per hectares, while in Khyber Pakhtunkhwa cultivated area under chickpea was 0.04 million hectare, with a production of 0.02 million tones and with an average yield of 0.58 tons per hectare [5]. Factors responsible for low production of chickpea are lack of high yielding varieties, no application of fertilizers and sensitivity of existing genotypes to different biotic and abiotic factors as compared to other crops.

In spite of its nutritional value and economic position the yield of chickpea is low and unstable in Pakistan due to cultivation of narrow genetic base cultivars, which are vulnerable to various stresses. Therefore it is necessary to develop a highly yielding and protein efficient varieties. High yielding varieties can be developed through simple selection of superior genotypes according to breeding methods. Grain yield is polygenic complex character, direct selection for yield is ineffective due to the presence of quantative interaction; therefore indirect selection of yield attributing traits should be done for developing superior variety [6]. For an efficient breeding program, the study of genetic parameters like genetic variance, environmental variance, phenotypic variance, heritability and genetic advance are necessary [7]. Keeping in view the above mentioned considerations this research was undertaken to assess genetic variability, heritability and genetic advance in F6 Population of Desi Chickpea (Cicer areitinum).

\section{Materials and methods}

The current research consist of 20 chickpea genotypes comprising of $19 \mathrm{~F}_{6}$ chickpea lines $\left(\mathrm{C}_{2}-\mathrm{P}_{2}-2-2, \mathrm{C}_{2}-\mathrm{P}_{4}-2-1, \mathrm{C}_{2}-\mathrm{P}_{4}-6-7, \mathrm{C}_{2}-\mathrm{P}_{5}-1-6\right.$, $\mathrm{C}_{2}-\mathrm{P}_{5}-2-2, \mathrm{C}_{2}-\mathrm{P}_{5}-2-3, \mathrm{C}_{2}-\mathrm{P}_{5}-2-5, \mathrm{C}_{2}-\mathrm{P}_{7}-1-1$, $\mathrm{C}_{2}-\mathrm{P}_{7}-1-5, \mathrm{C}_{2}-\mathrm{P}_{7}-1-6, \mathrm{C}_{2}-\mathrm{P}_{7}-1-8, \mathrm{C}_{2}-\mathrm{P}_{8}-1-1$, $\mathrm{C}_{2}-\mathrm{P}_{8}-1-4, \mathrm{C}_{2}-\mathrm{P}_{8}-1-6, \mathrm{C}_{2}-\mathrm{P}_{8}-2-3, \mathrm{C}_{2}-\mathrm{P}_{8}-2-5$, $\left.\mathrm{C}_{2}-\mathrm{P}_{8}-2-7, \mathrm{C}_{2}-\mathrm{P}_{8}-3-1, \mathrm{C}_{2}-\mathrm{P}_{8}-3-4\right)$ and one check cultivar (karak-1). These lines were derived from cross between two desi chickpea genotypes i.e. ICC-19181 and NDC-5-S10.The research was led at The University of Agriculture Peshawar during 2015-16. The F6 lines along with check cultivar were laid out in randomized complete block design using three replication. Row length was $4 \mathrm{~m}$, row to row and plant to plant distance was $30 \mathrm{~cm}$ and 10 $\mathrm{cm}$ respectively. Normal agronomic practices were performed during the growing period. Data was taken on 10 plants from each entry for 10 traits like: Days to maturity, Plant height, Primary branches plant ${ }^{-1}$, Secondary branches plant ${ }^{-1}$, Pods plant ${ }^{-1}$, Seeds pod ${ }^{-1}$. 100 Seed weight, Seed yield, Biological yield and harvest index. Data noted on yield and yield associated characters were subjected to analysis of variance (ANOVA), Variances, broad sense heritability and genetic advance were calculated according to Johnson et al. [8]. 


\section{Results and discussion}

Knowledge regarding genetic variability is prerequisite for improvement of any traits as it assist to understand the magnitude of genetic variation which offer the base for effective selection.

\section{Days to maturity}

Mean squares exhibited significant differences $(P \leq 0.01)$ among the $\mathrm{F}_{6}$ chickpea lines for days to maturity (Table 1). Days to maturity were ranged from 139.0 days for line $\mathrm{C}_{2}-\mathrm{P}_{2}-2-2$ to 170.3 days for line $\mathrm{C}_{2}-\mathrm{P}_{5}-1-$ 6 with the grand mean of 159.9 days (Table 2). The current results are in correspondence with Mukesh et al. and Zali et al. $[9,10]$ who also demonstrated significant difference for days to maturity among chickpea genotypes. Heritability its components and genetic advance for days to maturity are presented in (Table 3). Genetic variance (68.27) was greater than environmental variance (14.45) for days to maturity among $\mathrm{F}_{6}$ chickpea lines. High magnitude of heritability (0.83) was noted for days to maturity. Using $5 \%$ selection intensity, the genetic advance for days to maturity was 15.46 (Table 3). Our results are in line with Mushtaq et al. [11] and Sidramappa et al. [12], who also found high value of heritability for days to maturity.

Table 1. Mean squares of yield associated traits of $F_{6}$ lines of chickpea

\begin{tabular}{|c|c|c|c|c|}
\hline Traits & $\begin{array}{c}\text { Replications } \\
(\mathbf{d f}=2)\end{array}$ & $\begin{array}{l}\text { F6 lines } \\
(d f=19)\end{array}$ & $\begin{array}{c}\text { Error } \\
(\mathbf{d f = 3 8})\end{array}$ & $\begin{array}{l}\text { Coefficient of } \\
\text { variation }(\%)\end{array}$ \\
\hline Days to maturity & 54.47 & $219.27 * *$ & 14.45 & 2.38 \\
\hline Plant height & 6.02 & $31.91 * *$ & 1.87 & 2.21 \\
\hline Primary branches plant $^{-1}$ & 0.003 & $0.34 * *$ & 0.03 & 6.28 \\
\hline Secondary branches plant ${ }^{-1}$ & 0.24 & $2.80 * *$ & 0.25 & 7.54 \\
\hline Pods plant ${ }^{-1}$ & 0.75 & $33.77 * *$ & 2.97 & 7.69 \\
\hline Seeds pod ${ }^{-1}$ & 0.005 & $0.06 * *$ & 0.005 & 4.50 \\
\hline 100 seed weight & 0.17 & $8.69 * *$ & 0.44 & 2.73 \\
\hline Grain yield & 762.09 & $36529.64 * *$ & 1497.09 & 12.63 \\
\hline Biological yield & 13510.00 & $335655.98 * *$ & 23993.77 & 10.46 \\
\hline Harvest index & 8.91 & $64.57 * *$ & 10.25 & 15.76 \\
\hline
\end{tabular}

$* *=$ significant at $1 \%$ probability level

\section{Plant height (cm)}

Mean square exhibited significant difference $(P \leq 0.01)$ for plant height among $\mathrm{F}_{6}$ chickpea lines (Table 1). Plant height ranged from 53.6 $\mathrm{cm}$ for line $\mathrm{C}_{2}-\mathrm{P}_{8}-1-1$ to $68.3 \mathrm{~cm}$ for line $\mathrm{C}_{2}$ $\mathrm{P}_{8}-2-5$ with grand mean of $61.7 \mathrm{~cm}$ (Table 2). These findings are in correspondence with Akhtar et al. [13] and Malik et al. [14], who also demonstrated significant difference for plant height among chickpea genotypes. Genetic and environmental variances showed for plant height were 10.01 and 1.87 respectively among $\mathrm{F}_{6}$ chickpea lines. For plant height high heritability (0.84) was noted. While, the genetic advance was 5.98 (Table 3). Our findings are in close correspondence with Hasan et al. [15] and Mushtaq et al. [11], who also demonstrated high magnitude of heritability among chickpea genotypes for plant height.

\section{Primary branches plant ${ }^{-1}$ (No)}

Data regarding primary branches plant $^{-1}$ showed significant difference $(P \leq 0.01)$ in $\mathrm{F}_{6}$ chickpea lines (Table 1). Its mean value varied from 2.1 for line $\mathrm{C}_{2}-\mathrm{P}_{7}-1-6$ to 3.8 for line $\mathrm{C}_{2}-\mathrm{P}_{8}-2-5$ with the grand mean of 2.6 (Table 2). Our consequences are in correspondence with earlier findings of Zali et al. [10] and Hussain et al. [16], who also demonstrated significant differences for primary branches plant $^{-1}$.For primary branches plant ${ }^{-1}$ the Genetic variance $(0.11)$ 
was greater than environmental variance (0.03). High heritability (0.80) and genetic advance (0.60) was observed for primary branches plant ${ }^{-1}$ (Table 3 ). Our results are in conformity with Ali et al. [17], who also validated high magnitude of heritability for primary branches plant ${ }^{-1}$.

Table 2. Means performance of yield associated traits in $\mathrm{F}_{6}$ lines of chickpea

\begin{tabular}{|c|c|c|c|c|c|c|c|c|c|c|}
\hline $\begin{array}{c}\text { F6 }_{6} \\
\text { chickpea } \\
\text { lines }\end{array}$ & $\begin{array}{c}\text { Days to } \\
\text { maturity } \\
\text { (days) }\end{array}$ & $\begin{array}{c}\text { Plant } \\
\text { height } \\
\text { (cm) }\end{array}$ & $\begin{array}{c}\text { Primary } \\
\text { branches } \\
\text { plant }^{-1}(\text { No) }\end{array}$ & $\begin{array}{l}\text { Secondary } \\
\text { branches }^{-1} \\
\text { plant }^{-1}(\mathrm{No})\end{array}$ & $\begin{array}{c}\text { Pods } \\
\text { plant }^{-1} \\
\text { (No) }\end{array}$ & $\begin{array}{l}\text { Seed } \\
\text { pod }^{-1} \\
(\text { No })\end{array}$ & $\begin{array}{c}100 \text { seed } \\
\text { weight } \\
\text { (g) }\end{array}$ & $\begin{array}{c}\text { Grain } \\
\text { yield } \\
\left(\mathrm{kg} \mathrm{ha}^{-1}\right)\end{array}$ & $\begin{array}{c}\text { Biologic } \\
\text { al yield } \\
\left(\mathrm{kg} \mathrm{ha}^{-1}\right)\end{array}$ & $\begin{array}{c}\text { Harvest } \\
\text { index } \\
(\%)\end{array}$ \\
\hline $\mathrm{C}_{2}-\mathrm{P}_{2}-2-2$ & 139.0 & 61.9 & 2.5 & 7.4 & 23.0 & 1.4 & 25.1 & 355.3 & 1598.3 & 22.2 \\
\hline $\mathrm{C}_{2}-\mathrm{P}_{4}-2-1$ & 168.7 & 62.5 & 2.6 & 7.5 & 25.2 & 1.2 & 18.0 & 431.6 & 1840.0 & 23.5 \\
\hline $\mathrm{C}_{2}-\mathrm{P}_{4}-6-7$ & 143.7 & 61.7 & 2.4 & 7.6 & 25.7 & 1.4 & 25.8 & 357.7 & 1449.4 & 24.7 \\
\hline $\mathrm{C}_{2}-\mathrm{P}_{5}-1-6$ & 170.3 & 58.9 & 2.5 & 5.9 & 19.7 & 1.5 & 24.8 & 146.5 & 1036.7 & 14.2 \\
\hline $\mathrm{C}_{2}-\mathrm{P}_{5}-2-2$ & 165.3 & 58.6 & 2.5 & 5.8 & 21.6 & 1.5 & 23.5 & 149.9 & 1081.1 & 13.6 \\
\hline $\mathrm{C}_{2}-\mathrm{P}_{5}-2-3$ & 147.3 & 64.4 & 2.5 & 8.0 & 22.1 & 1.6 & 25.3 & 459.6 & 1896.7 & 25.1 \\
\hline $\mathrm{C}_{2}-\mathrm{P}_{5}-2-5$ & 160.7 & 66.4 & 2.8 & 7.3 & 23.8 & 1.5 & 24.4 & 401.9 & 1874.7 & 21.4 \\
\hline $\mathrm{C}_{2}-\mathrm{P}_{7}-1-1$ & 155.0 & 58.6 & 2.3 & 4.7 & 17.1 & 1.9 & 23.3 & 421.7 & 1525.0 & 27.7 \\
\hline $\mathrm{C}_{2}-\mathrm{P}_{7}-1-5$ & 153.7 & 62.9 & 2.9 & 5.5 & 22.2 & 1.4 & 25.5 & 360.0 & 1525.6 & 23.6 \\
\hline $\mathrm{C}_{2}-\mathrm{P}_{7}-1-6$ & 161.7 & 61.0 & 2.1 & 6.1 & 23.9 & 1.4 & 24.3 & 257.7 & 1755.1 & 14.7 \\
\hline $\mathrm{C}_{2}-\mathrm{P}_{7}-1-8$ & 154.0 & 65.1 & 2.4 & 7.3 & 26.9 & 1.5 & 25.9 & 463.8 & 1976.7 & 24.5 \\
\hline $\mathrm{C}_{2}-\mathrm{P}_{8}-1-1$ & 160.7 & 53.6 & 2.7 & 6.6 & 18.5 & 1.4 & 23.2 & 210.3 & 1065.0 & 19.8 \\
\hline $\mathrm{C}_{2}-\mathrm{P}_{8}-1-4$ & 168.0 & 60.4 & 2.6 & 7.0 & 26.0 & 1.7 & 24.2 & 245.5 & 1446.7 & 16.9 \\
\hline $\mathrm{C}_{2}-\mathrm{P}_{8}-1-6$ & 162.7 & 63.1 & 2.5 & 6.8 & 17.7 & 1.5 & 25.6 & 118.6 & 1016.7 & 11.7 \\
\hline $\mathrm{C}_{2}-\mathrm{P}_{8}-2-3$ & 164.0 & 62.0 & 2.4 & 6.1 & 23.5 & 1.5 & 24.0 & 409.6 & 1540.0 & 26.6 \\
\hline $\mathrm{C}_{2}-\mathrm{P}_{8}-2-5$ & 163.0 & 68.3 & 3.8 & 6.4 & 19.2 & 1.6 & 24.6 & 351.6 & 2010.6 & 17.5 \\
\hline $\mathrm{C}_{2}-\mathrm{P}_{8}-2-7$ & 167.3 & 58.1 & 2.7 & 5.9 & 21.7 & 1.4 & 23.6 & 196.1 & 1077.2 & 18.2 \\
\hline $\mathrm{C}_{2}-\mathrm{P}_{8}-3-1$ & 164.7 & 62.0 & 2.6 & 6.0 & 28.8 & 1.5 & 25.6 & 284.1 & 1419.6 & 20.0 \\
\hline $\mathrm{C}_{2}-\mathrm{P}_{8}-3-4$ & 163.0 & 64.1 & 2.5 & 8.8 & 24.7 & 1.5 & 24.3 & 201.1 & 1161.7 & 17.3 \\
\hline Karak-1 & 165.0 & 61.4 & 2.9 & 6.3 & 17.2 & 1.5 & 24.7 & 304.1 & 1308.3 & 23.2 \\
\hline Mean & 159.9 & 61.7 & 2.6 & 6.6 & 22.4 & 1.5 & 24.3 & 306.3 & 1480.2 & 20.3 \\
\hline Minimum & 139.0 & 53.6 & 2.1 & 4.7 & 17.1 & 1.2 & 18.0 & 118.6 & 1016.7 & 11.7 \\
\hline Maximum & 170.3 & 68.3 & 3.8 & 8.8 & 28.8 & 1.9 & 25.9 & 463.8 & 2010.6 & 27.7 \\
\hline $\operatorname{LSD}_{(0.05)}$ & 6.3 & 2.3 & 0.3 & 0.8 & 2.8 & 0.1 & 1.1 & 64.0 & 256.0 & 5.3 \\
\hline
\end{tabular}

\section{Secondary branches plant ${ }^{-1}(\mathrm{No})$}

Mean squares exhibited significant difference $(P \leq 0.01)$ among $\mathrm{F}_{6}$ chickpea lines for secondary branches plant ${ }^{-1}$ (Table 1). Its mean value ranged from 4.7 for line $\mathrm{C}_{2}-\mathrm{P}_{7}-1$ 1 to 8.8 for line $\mathrm{C}_{2}-\mathrm{P}_{8}-3-4$ with a grand mean value of 6.6 (Table 2). These consequences are in argument with experimental work of and Ali et al. [18], who also demonstrated significant difference for secondary branches plant $^{-1}$ in chickpea lines. Table 3 showed that for secondary branches plant ${ }^{-1}$ the genetic variance $(0.85)$ was greater than environmental variance (0.25). High heritability (0.77) and genetic advance (1.67) was noted for secondary branches plant ${ }^{-1}$ (Table 3). The contemporary findings are in correspondence with Mushtaq et al. [11] and Ali et al. [19], who also noted high heritability in chickpea genotypes for secondary branches plant ${ }^{-1}$.

Pods plant $^{-1}$ (No)

Mean squares exhibited significant difference $(P \leq 0.01)$ among $\mathrm{F}_{6}$ chickpea lines for pods plant ${ }^{-1}$ (Table 1). Its mean values were ranged from 17.1 for $\mathrm{C}_{2}-\mathrm{P}_{7}-1-1$ to 28.8 
for $\mathrm{C}_{2}-\mathrm{P}_{8}-3-1$ with average value of 22.4 pods plant $^{-1}$ (Table 2). The above findings are in agreement with Babbar et al. [20], who observed significant difference for pods plant $^{-1}$ in chickpea. Genetic variance (10.27) was 3.45 time greater than environmental variance (2.97) for pods plant $^{-1}$ among $\mathrm{F}_{6}$ chickpea genotypes. High heritability (0.78) and genetic advance (5.81) was observed for pods plant ${ }^{-1}$ (Table 3 ). The current findings are in agreement with findings of Sidramappa et al. and Ali et al. $[12,17]$. They also noted high value of heritability for the said trait in chickpea.

Table 3. Variances, heritability and genetic advance of $F_{6}$ lines of chickpea

\begin{tabular}{|c|c|c|c|c|c|c|}
\hline Traits & $\begin{array}{c}\text { Genotypic } \\
\text { variance } \\
(\mathbf{V g})\end{array}$ & $\begin{array}{c}\text { Environmen } \\
\text {-tal variance } \\
(\mathbf{V e})\end{array}$ & $\begin{array}{c}\text { Phenotypic } \\
\text { variance } \\
(\mathbf{V p})\end{array}$ & $\begin{array}{c}\text { Heritability } \\
(\mathbf{b . s})\end{array}$ & $\begin{array}{c}\text { Genetic } \\
\text { advance } \\
(\mathbf{G A})\end{array}$ & $\mathbf{G A} \overline{\mathbf{X})}$ \\
\hline Days to maturity & 68.27 & 14.45 & 82.72 & 0.83 & 15.46 & 9.67 \\
\hline Plant height & 10.01 & 1.87 & 11.88 & 0.84 & 5.98 & 9.69 \\
\hline Primary branches plant $^{-1}$ & 0.11 & 0.03 & 0.13 & 0.80 & 0.60 & 22.99 \\
\hline Secondary branches plant $^{-1}$ & 0.85 & 0.25 & 1.10 & 0.77 & 1.67 & 25.10 \\
\hline Pods plant $^{-1}$ & 10.27 & 2.97 & 13.24 & 0.78 & 5.81 & 25.94 \\
\hline Seeds pod $^{-1}$ & 0.02 & 0.00 & 0.02 & 0.79 & 0.24 & 16.20 \\
\hline 100 seed weight $_{\text {Grain yield }}^{2.75}$ & 0.44 & 3.19 & 0.86 & 3.17 & 13.07 \\
\hline Biological yield & 11677.52 & 1497.09 & 13174.61 & 0.89 & 209.58 & 68.42 \\
\hline Harvest index & 103887.40 & 23993.77 & 127881.18 & 0.81 & 598.45 & 40.43 \\
\hline
\end{tabular}

\section{Seed $\operatorname{pod}^{-1}$ (No)}

Seed $\operatorname{pod}^{-1}$ showed significant difference $(P \leq$ 0.01 ) among $F_{6}$ chickpea lines (Table 1). Mean values of seed pod $^{-1}$ ranged from 1.2 for $\mathrm{C}_{2}-\mathrm{P}_{4}-2-1$ to 1.9 for $\mathrm{C}_{2}-\mathrm{P}_{7}-1-1$ with average value of 1.5 seed pod $^{-1}$ (Table 2), similar findings were also mentioned by Naveed et al. [1] for seed $\operatorname{pod}^{-1}$ in chickpea populations. Genetic variance (0.02) was 0.02 times greater than environmental variance $(0.00)$ for the said trait. Seed $\operatorname{pod}^{-1}$ showed high magnitude of heritability (0.79) and genetic advance (0.24) for seed pod $^{-1}$ (Table 3). Mushtaq et al. [11] and Ali et al. [15] also noted high magnitude of heritability associated with high genetic advance (0.24) for seed pod $^{-1}$.

\section{0 seed weight $(\mathrm{g})$}

Data regarding 100 seed weight revealed significant difference $(P \leq 0.01)$ among $\mathrm{F}_{6}$ Chickpea lines (Table 1). Mean values of 100 seed weight ranged from $18.0 \mathrm{~g}$ for line $\mathrm{C}_{2}-$ $\mathrm{P}_{4}-2-1$ to $25.9 \mathrm{~g}$ for line $\mathrm{C}_{2}-\mathrm{P}_{7}-1-8$ with average value of $24.3 \mathrm{~g}$ (Table 2). Our consequences are in correspondence with prior results of Zali et al. [10], who also found significant difference for 100 seed weight in chickpea genotypes. Genetic variance $(2.75)$ was 6.25 times greater than environmental variance $(0.44)$ for 100 seed weight. Therefore high magnitude of broad scene heritability $(0.86)$ and genetic advance of (3.17) was observed for 100 seed weight. (Table 3). These results are in correspondence with Hasan et al. [21], who also examined high heritability and genetic advance for 100 seed weigh.

\section{Grain yield ( $\mathrm{kg} \mathrm{ha}^{-1}$ )}

Mean squares for grain yield revealed significant difference $(P \leq 0.01)$ among the $\mathrm{F}_{6}$ chickpea lines (Table 1). Mean data ranged from $118.6 \mathrm{~kg} \mathrm{ha}^{-1}$ for line $\mathrm{C}_{2}-\mathrm{P}_{8}-1-6$ to 463.8 $\mathrm{kg} \mathrm{ha}^{-1}$ for line $\mathrm{C}_{2}-\mathrm{P}_{7}-1-8$ with a grand mean of $306.3 \mathrm{~kg} \mathrm{ha}^{-1}$ (Table 2). Genetic variance for grain yield was 11677.52 while environmental variance was 1497.09. High magnitude of broad scene heritability $(0.89)$ 
was found for grain yield and the genetic advance for grain yield was 209.58 (Table 3). Our consequences are in correspondence with Ali et al. [19] and Chandra et al. [22], who also noted high magnitude of heritability and genetic advance for grain yield in chickpea genotypes.

\section{Biological yield ( $\left.\mathrm{kg} \mathrm{ha}^{-1}\right)$}

Significant differences $(P \leq 0.01)$ was observed for biological yield among $F_{6}$ chickpea lines (Table 1). Mean value of biological yield ranged from $1016.7 \mathrm{~kg} \mathrm{ha}^{-1}$ for line $\mathrm{C}_{2}-\mathrm{P}_{8}-1-6$ to $2010.6 \mathrm{~kg} \mathrm{ha}^{-1}$ for $\mathrm{C}_{2}-\mathrm{P}_{8}$ $2-5$ with a grand mean of $1480.2 \mathrm{~kg} \mathrm{ha}^{-1}$ (Table 2). Genetic variance (103887.40) was 44.32 times greater than environmental variance (23993.77) for biological yield. Heritability observed for biological yield was 0.81. While genetic advance was 598.45 (Table 3). These findings are in correspondence with findings of Malik et al. [14] and Chandra et al. [22].

\section{Harvest index (\%)}

Data regarding harvest index demonstrated significant differences $(P \leq 0.01)$ among $\mathrm{F}_{6}$ chickpea lines (Table 1). Harvest index ranged from $11.7 \%$ for $\mathrm{C}_{2}-\mathrm{P}_{8}-1-6$ to $27.7 \%$ for $\mathrm{C}_{2}-\mathrm{P}_{7}-1-1$ with mean value of $20.3 \%$ (Table 2). Our results are in line with findings of Hasan et al. [21] and Chandra et al. [22], who noted significant differences for harvest index. Genetic variance of harvest index was 18.10 while environmental variance was 10.25. Heritability observed for harvest index was 0.64 , while the genetic advance was 7.00 (Table 3). Saki et al. [23] and Malik et al. [24] also noted high heritability for harvest index in chickpea lines.

\section{Conclusion}

Highly significant differences were noted among $F_{6}$ desi chickpea lines for all the studied traits, showed that there is enough variability for effective selection. Likewise, high heritability coupled with high genetic advance were noted for most of traits, specifying that those traits are under genetic control as compare to environmental influence and selection could lead to quick improvement. Lines: $\mathrm{C}_{2}-\mathrm{P}_{7}-1-8$ and $\mathrm{C}_{2}-\mathrm{P}_{5}-2-$ 3 revealed maximum mean value for grain yield and could be taken into consideration in feature breeding program.

\section{Authors' contributions}

Conceived and designed the experiments: S Ali \& A Sohail, Performed the experiments: MK Nawaz, Analyzed the data: A Sohail, Contributed reagents/ materials/ analysis tools: T Burni, S Bahar, Manzoor, \& Q Hussain, Wrote the paper: A Sohail.

\section{References}

1. Naveed M, Shafiq M, Rafiq CM \& Zahid MA (2015). Genetic diversity in new chickpea accessions for fusarium wilt resistance, canopy temperature and yield components under drought milieus. Australian J Crop Sci 9(6): 538-544.

2. Bakhsh A, Malik SR, Iqbal U \& Arshad W (2007). Heterosis and heritability studies for superior segregants selection in chickpea. Pak J Bot 39(7): 2443-2449.

3. Khan S (2011) Breeding of Pulse Crops 2(1): 126-138.

4. FAO (2016). Food and Agriculture organization.

5. Pakistan Agriculture Statistics of Pakistan, Ministry of food (2014-15), Agriculture and Livestock Islamabad.

6. Roy A, Ghosh S \& Kundagrami S (2013). Genetic Approach and Biometrical Association of Yield Attributing Traits in Chickpea (Cicer arietinium L.). Inter J Sci \& Res 5(7): 2208-2212.

7. Gul R, Khan H, Bibi M, Ain QU \& Imran B (2013). Genetic analysis and interrelationship of yield attributing traits in Chickpea (Cicer arietinum L.). J Anim Pl Sci 23(2): 521-526.

8. Johnson HW, Robinson HF \& Comstock RE (1955). Estimates of genetic and environmental variability in soybeans. Agron J 47: 314-318. 
9. Mukesh K, Kushwaha S, Dwivedi VK \& Dhaka SS (2016). Genetic variability and correlation analysis of various traits in chickpea genotypes (Cicer arietinum L.) under rainfed condition in western Uttar Pradesh. Inter J Advanced Eng Res and Sci 3(9): 150-156.

10. Zali H, Farshadfar E \& Sabaghpour SH (2011). Genetic variability and interrelationships among agronomic traits in chickpea (Cicer arietinum L.) genotypes. Crop Br J 1(2): 127-132.

11. Mushtaq MA, Bajwa MM \& Saleem M (2013). Estimation of genetic variability and path analysis of grain yield and its components in chickpea (Cicer arietinum L.). Inter J Sci \& Eng Res 4(1): 1-4.

12. Sidramappa SA, Patil PM, Salimath \& Kajjidoni ST (2008). Genetic Variation for Productivity and its Related Traits in a Recombinant Inbred Lines Population of Chickpea. Karnataka J Agric Sci 21(4): 488-490.

13. Akhtar LH, Pervez MA \& Nasim M (2011). Genetic divergence and interrelationship studies in chickpea (Cicer arietinum L.). Pak J Agri Sci 48(1): 3539.

14. Malik SR, Bakhsh A, Asif MA, Iqbal U \& Iqbal SM (2010). Assessment of genetic variability and interrelationship among some agronomic traits in chickpea. Int J Agric Biol 12: 81-85.

15. Hasan UE, Arshad M, Ahsan M \& Saleem M (2008). Genetic variability and interrelationship for granin yield and its various components in chickpea (Cicer arietinum L.). J Agric Res 46(2): 109-116.

16. Hussain N, Ghaffar A, Aslam M, Hussain K \& Naeem-ud-Din. (2016). Assessment of genetic variation and mode of inheritance of some Quantitative traits in chickpea (Cicer arietinum 1.). The J Anim \& Pl Sci 26(5): 1334-1338.

17. Ali Q, Tahir MHN, Sadaqat HA, Arshad S, Farooq J, Ahsan M, Waseem M \& Iqbal A (2011). Genetic variability and correlation analysis for quantitative traits in chickpea genotypes (Cicer arietinum L.). J Bacteriol Res 3(1): 6-9.

18. Ali Q, Ahsan M, Farooq J \& Saleem M (2010). Genetic variability and trait association in chickpea (Cicer arietinum L.). Electronic J Pl Br 1(3): 328-333.

19. Ali Q \& Ahsan M (2012). Estimation of Genetic Variability and Correlation Analysis for Quantitative Traits in Chickpea (Cicer arietinum L.). Inter $J$ for Agro Vet Medic Sci 6(4): 241-249.

20. Babbar A, Prakash V, Tiwari P \& Iquebal MA (2012). Genetic variability for chickpea (cicer arietinum 1.) Under late sown season. Legume Res 35(1): 17.

21. Hasan MT \& Deb AC (2017). Assessment of genetic variability, heritability, character association and selection indexes in chickpea (Cicer arietinum L.). Int J Biosci 10(2): 111129.

22. Chandra K, Lal GM \& Singh CM (2015). Estimates of genetic variability and scope of selection for yield determinants in mutated populations of chickpea (Cicer arietinum L.). Legume Res 38(5): 563-569.

23. Saki AI, Zaman MA, Tuhina-Khatun M, Kamal MM \& Begum H (2009). Genetic Variability, Correlation and Path CoEfficient Analysis for Agronomic Traits in Chickpea (Cicer arietinum L.). The Agriculturists 7(1): 12-21.

24. Malik SR, Bakhsh A, Asif MA, Iqbal U \& Iqbal SM (2011). Genetic variability and correlation among yield traits in chickpea. Int J Agric Biol 15(1): 101106. 